\title{
Kontaminasi Tembaga pada Mugil dussumieri (Actinopterygii: Mugilidae, Forsskal, 1775) yang Ditangkap di Perairan Semarang, Indonesia
}

\author{
Chrisna Adhi Suryono*, Endang Sri Susilo, Aldo Rizqi Arinianzah, Wilis Ari Setyati, \\ Irwani dan Suryono
}

\author{
Departemen IImu Kelautan, Fakultas Perikanan dan IImu Kelautan, Universitas Diponegoro \\ Jl. Prof. Soedarto, SH. Tembalang, Semarang 50275 Indonesia \\ Email: chrisna_as@yahoo.com
}

\begin{abstract}
Contamination of Copper in Mugil dussumeri (Actinopterygii: Mugilidae, Forsskal, 1775) which was caught in Semarang waters, Indonesia
\end{abstract}

The marine environment in Semarang waters are highly polluted by heavy metals such as copper (Cu). On the other side, these areas have become producers of fishery commodities such as mullet fish Mugil dussumieri. The aims of this study was to determine the heavy metal content of $\mathrm{Cu}$ in mullet fish during wet monsoon (December 2017 and February 2018). Atomic Absorption Spectrophotometer were used to analysis of Cu concentration in marine water and fish meat. The results show that the Cu content in marine water was not detected while in the meat of mullet fish during December 2017 and February 2018 were $0.66 \pm 0.07 \mathrm{mg} / \mathrm{kg}$ and $0,604 \pm 0.217 \mathrm{mg} / \mathrm{kg}$, respectively. The results were still within the quality standard for maximum limit of $\mathrm{Cu}$ content allowed in seafood by FAO/WHO.

Keywords: Contamination; Copper; Marine Water; Mullet Fish; Wet Monsun

\begin{abstract}
Abstrak
Lingkungan perairan laut di sekitar Semarang berpeluang sangat tinggi untuk terpolusi logam berat tembaga. Di lain sisi perairan ini menjadi daerah produksi perikanan seperti ikan belanak Mugil dussumieri. Tujuan dari penelitian ini adalah untuk mengetahui kandungan logam Cu dalam daging ikan belanak yang ditangkap selama musim penghujan (Desember 2017 dan Februari 2018). Untuk mengetahui konsentrasi Cu dalam air laut dan ikan belanak digunakan Atomic Absorption Spectrophotometer. Hasil penelitian menunjukkan bahwa konsentrasi logam Cu selama bulan Desember 2017 adalah $0.66 \pm 0.07 / \mathrm{kg}$ dan selama bulan Februari 0,604 \pm 0.217 $\mathrm{mg} / \mathrm{kg}$, sedangkan konsentrasi Cu dalam air laut tidak terdeteksi. Hasil penelitian dapat disimpulkan bahwa kandungan Cu dalam ikan belanak masih berada pada konsentrasi yang diperbolehkan oleh FAO/WHO.
\end{abstract}

Kata kunci: Kontaminasi; Tembaga; Air Laut; Ikan Belanak; Musim Penghujan

\section{PENDAHULUAN}

Belanak merupakan ikan laut yang mampu berdadaptasi pada kisaran salinitas yang luas dan menyebar sangat luas didaerah tropis sampai sub tropis (FAO, 1974). Pesisir Semarang merupakan salah satu habitat dimana ikan tersebut ditemukan.
Namun permasalahan yang ada di perairan Semarang adalah tingginya pemanfaatan pesisir tersebut untuk berbagai kepentingan seperti pelabuhan umum, pelabuhan perikanan, kawasan industri, pemukiman, pariwisata, pertambakan dan buangan limbah (Suryono \& Rochaddii, 2017). Penggunaan wilayah pesisir untuk berbagai 
penelitian telah menunjukan bahwa pesisir Semarang telah tercemar (Suryono, 2016a; Suryono, 2016b). Logam berat baik yang berasal dari alam maupun antropogenik telah ditemukan dalam perairan dan terakumulasi dalam tubuh ikan melalui makanan maupun insang (EFSA, 2005). Beberapa karakter air laut seperti arus, temperatur, $\mathrm{pH}$, cahaya matahari dan penguapan yang selalu berubah tiap musim akan berpengaruh terhadap bioavailability polutan dalam air maupun sedimen (EPA, 2004; Eckley and Branfireun, 2009). Hal tersebut menunjukan adanya hubungan antara akumulasi logam berat dalam tubuh ikan (Vicente-Martorell et al, 2009). Kemampuan ikan dalam mengakumulasi logam berat dalam perairan tergantung pada musim dan juga akan memberi dampak yang berbeda terhadap kesehatan manusia yang menkonsumsinya (Nevárez, 2015).

Kontaminasi logam berat dalam ikan ternyata telah dilaporkan di beberapa wilayah di dunia seperti laut Merah Mesir, yang ditemukannya logam $\mathrm{Cu}, \mathrm{Zn}, \mathrm{Pb}, \mathrm{Cd}$, Fe dan $M n$ di dalam hati, insang dan daging pada ikan pelagis dan demersal (El-Moselhy, et al, 2014). Logam $\mathrm{Cd}, \mathrm{As}, \mathrm{Hg}, \mathrm{Pb}, \mathrm{Zn}$ dan $\mathrm{Cu}$ juga ditemukan pada jarinagn pernapasan, penyerapan dan pencernakan diberbagai ikan konsumsi yang ditangkap d laut Hitam Bulgaria (Makedonski et al, 2017).

Logam $\mathrm{Cd}, \mathrm{Pb}, \mathrm{Cr}, \mathrm{Ni}, \mathrm{Cu}$ dan $\mathrm{Zn}$ telah terditeksi dalam daging empat jenis ikan ekonomis penting seperti Thunnus obesus, Decapterus lajang, Cubiceps squamiceps dan Priacanthus macracanthus yang ditangkap di laut Cina Selatan (Gu et al, 2017). Keberadaan logam berat seperti $C d$, $\mathrm{Cr}, \mathrm{Cu}, \mathrm{Ni}, \mathrm{Pb}$, dan $\mathrm{Zn}$ juga ditemukan pada beberapa jenis ikan seperti Epinephelus areolatus, Lutjanus russelli, and Sparus sarba yang dipelihara di laut Hong Kong (Wong et al, 2001). Beberapa jenis ikan belanak yang ditangkap di beberapa perairan diberbagai negara seperti laut Brazil, Teluk Persia, pelabuhan Mumbai India dan laut Arab juga telah terkontaminasi oleh logam berat (Hauser-Davis, 2016; Bastami et al, 2015). Keluarga ikan Mugilidae berperan besar pada perdagangan ikan di dunia seperti jenis
Liza klunzingeri yang merupakan ikan penting dalam perikanan tangkap maupun budidaya di Teluk Persia. Ikan tersebut meupakan ikan pelagis yang menyebar di Samudra India, Laut Arab dan Teluk Oman (Bastami et al, 2015). Cara makanan ikan belanak dengan cara meyaring air dan meyerap detritus yang ada di lumpur sehingga ikan tersebut sangat mudah terkontaminasi oleh logam berat yang terdapat dalam air maupun sedimen. Sampai saat ini penelitian kontaminasi logam berat terhadap ikan yang ditangkap di perairan Semarang belum pernah dilakukan, meskipun penelitian serupa talah banyak dilakukan di bergai negara. Maka dari itu penelitian ini bertujuan mengetahu kontaminasi ikan belakan yang ditangkap pada saat musim hujan di perairan Semarang.

\section{MATERI DAN METODE}

Materi yang digunakan dalam penelitian ini adalah air laut dan daging ikan belanak yang diambil di pesisir Semarang pada bulan Desember 2017 dan Februari 2018. pada masing masing bulang dikalukan tiga kali pengambilan dengan selang waktu 1 minggu. Sampel air laut diambil dengan menggunakan Nansen Botle sedangkan ikan belanak dengan menggunakan girl nett. Logam berat Cu dalam air maupun daging ikan dianalisa menggunakan AAS (ShimadzU 7000, Japan) berdasarkan prosedur (FAO/SIDA, 1983).

Hasil pengukuran logam berat dalam air dan daging ikan digunakan untuk mengukur Faktor Kontaminasi (CF) dan Indek Pulusi Logam (MPI). Faktor Kontaminasi (CF) $=\mathrm{Cf}=$ $\mathrm{Co} / \mathrm{Cb}$, dimana $\mathrm{Co}=$ konsentarsi logam dalam sampel biota dan $\mathrm{Cb}=$ konsentrasi logam di alam (air laut), modifikasi (Çevik et al., 2009; El-Sorogy et al., 2016). Sedangkan Indek Pulusi Logam (MPI) $=(\mathrm{Cf} 1 \times \mathrm{Cf} 2 \ldots \mathrm{C} \mathrm{fn}) / \mathrm{n}$ dimana $\mathrm{Cfl}$ adalah konsentrasi logam pada sampel 1 dan Cfn adalah konsentrasi logam pada sampel ke-n sedangkan $n$ adalah jumlah sampel yang dianalisa, modifikasi (Liu et al 2017)

\section{HASIL DAN PEMBAHASAN}

Hasil penelitian terhadap kontaminasi logam Cu (Tembaga) yang terdapat dalam 
daging ikan belanak dan perairan dimana ikan belanak tersebut ditangkap selama musim penghujan dapat dilihat (Tabel 1). Hasil penelitian menunjukan bahwa ikan belanak yang ditangkap di pesisir Semarang mengindikasikan terkontaminasi oleh logam Cu dengan perbagai konsentrasi 10.39 - 0.77 $\mathrm{mg} / \mathrm{kg}$ ). Konsentrasi Cu pada daging ikan terlihat pada bulan Desember 2017 lebih tinggi dari pada bulan Februari 2018. Namun konsentrasi Cu pada daging ikan masih layak dikonsumsi karena masih dibawah $1 \mathrm{mg} / \mathrm{kg}$ standar yang diperkenankan (FAO/WHO, 2004). Demikian juga konsentrasi Cu yang terdapat dalam air laut masih layak untuk kehidupan organisme laut karena masih dibawak $0.008 \mathrm{mg} / \mathrm{L}$ (Kepmen LH, 2004). Konsentrasi $\mathrm{Cu}$ yang terdapat dalam daging ikan belanak yang diambil pada bulan Desember dan Februari bila diuji dengan one way ANOVA menunjukan tidak ada perbedaan $(0.005<\mathrm{p}=0.905)$.

Bila dilihat dari faktor kontaminasi (CF) logam Cu terhadap daging ikan belanak nenunjukan bahwa sampel yang diambil pada bulan Desember > daripada yang diambil pada bulan Februari. Demikian juga nilai faktor kontaminasi antara bulan Desember dan Februari bila diuji dengan One Way ANOVA tidak menunjukan adanya perbedaan $10.005<$ $\mathrm{p}=0.908$ ). Indek pulusi logam Cu (MPI) pada daging ikan belanak juga menunjukan ikan yang ditangkap pada bulan Desember lebih besar daripada bulan Februari. Banyak faktor yang mempengaruhi masuknya logam dalam tubuh ikan termasuk umur, daerah distribusi ikan dan faktor spesifik pada ikan (El-Moselhy et al,2014). Umur ikan disini direfleksikan dalam ukuran ikan, dimana ikan yang didapat pada bulan Desember lebih besar daripada bulan Februari hal tersebut yang diduga menyebabkan tingginya $\mathrm{Cu}$ pada bulan Desember.

Permasalahannya sebenarnya tidak hanya masih rendahnya konsentrasi logam dalam air laut saat ini dan masih rendahnya konsentrasi logam dalam ikan. Namun masalah masukan logam ke dalam lingkungan laut baik secara alami maupun akibat aktifitas manusia semakin meningkat. Kondisi ini tentunya menimbulkan masalah terhadap kontaminasi ikan oleh logam berat diwaktu yang akan datang akan meningkat. Apalagi permintaan akan ikan untuk konsumsi semakin meningkat dengan semakin meningkatnya kebutuhan protein, nutrisi yang berkualitas, asam lemak tidak jenuh dan asam lemak yang mengandung omega-3 (Bosch et al., 2016; Golden et al., 2016). Pencemaran logam berat di laut dan kontaminasi ikan oleh lagam berat telah menjadi perhatian yang serius tidak hanya untuk kesehatan ikan, namun juga terhadap dampak buruk yang diakibatkan bila dikonsumsi manusia (Gu et al., 2016). Meskipun logam Cu memiliki peran penting dalam sistem biologi namun jika konsentrasinya meningkat diatas ambang akan menjadi racun bagi ikan dan lingkunganya (Liu et al., 2015). Apalagi masukan logam dalam tubuh ikan akan terakumulasi tidak hanya berasal

Tabel 1. Konsentrasi Cu dalam air laut dan daging ikan belanak yang ditangkap di perairan Semarang

\begin{tabular}{lcccccc}
\hline \multirow{2}{*}{$\begin{array}{c}\text { Bulan } \\
\text { Sampling }\end{array}$} & $\begin{array}{c}\text { Minggu } \\
\text { Sampling }\end{array}$ & $\begin{array}{c}\text { Air Laut } \\
(\mathrm{mg} / \mathrm{L})\end{array}$ & $\begin{array}{c}\text { Daging } \mathrm{kan} \\
(\mathrm{mg} / \mathrm{kg})\end{array}$ & $\begin{array}{c}\text { Rata Rata } \\
(\mathrm{mg} / \mathrm{kg}) \pm \text { SD }\end{array}$ & CF \pm SD & MPI \\
\cline { 3 - 5 } & 1 & $<0.001$ & 0.72 & & & \\
Desember & 2 & $<0.001$ & 0.66 & $0.66 \pm 0.07$ & $656.7 \pm$ & 0.093 \\
2017 & 3 & $<0.001$ & 0.59 & & 65.06 & \\
& 1 & $<0.001$ & 0.76 & & & \\
Februari & 2 & $<0.001$ & 0.39 & $0.64 \pm 0.217$ & $640.0 \pm$ & 0.076 \\
2018 & 3 & $<0.001$ & 0.77 & & 216.6 & \\
\hline
\end{tabular}

Ket. 0.008 (mg/L) batas maksimum yang diperbolehkan untuk kehidupan biota laut Kepmen LH no 51 th 2004 ;

1 (mg/kg) batas maksimum kadar Cu untuk hasil laut yang dikonsumsi FAO/ WHO 
dari makanan ikan namun juga berasal dari air dan sedimen (Yi et al., 2011; Jayaprakash et al., 2015). Bioakumulasi lagam pada ikan sebenarnya dapat menyebabkan dampak jangka panjang pada siklus biogekimiawi (Sapkota et al., 2008). Dimana akumulasi logam bersamaan dengan peningkatan tingkat tropik dapat menyebapkan resiko yang nyata terhadap kesehatan bila mengkonsumsinya diatas jumlah yang aman. Maka dari itu sangat penting mengetahui akumulasi logam berat dalam organisme air terutama yang terdapat dalam ikan yang menjadi makanan manusia secara umum. Meskipun logam berat telah dibuktikan kebaradaannya dalam lingkungan laut namun di Indonesia terutama di Semarang belum menjadi perhatian yang utama meskipun di beberapa negara Asia telah dilakukan monitor terhadap logam berat yang terkait dengan ikan. Sebenarnya ikan belanak termasuk ikan yang mudah terkontaminasi logam berat hal tersebut dikarenakan dari pola makan yang menghisap plankton dari air dan memakan detritus dari lapisan sedimen (Hauser-Davis et al, 2016). Disamping itu ikan tersebut kebanyakan hidup di tepi pantai yang masukan (Bastami et al, 2015). Maka dari itu apabila ikan belanak yang ditangkap dispesisir Semarang telah terkontamninasi oleh logam berat Cu karena pada dasarnya perairan tersebut juga telah terkontaminasi logam berat baik dalam air maupun sedimen (Suryono, 2016a; Suryono, 2016b; Suryono, \& Djunaedi, 2017)

\section{KESIMPULAN}

Hasil penelitian kontaminasi Cu pada ikan belanak dapat disimpulka bahwa ikan belanak yang ditangkap di perairan Semarang telah terkontaminiasi logam Cu $0.66 \pm 0.07$ $\mathrm{mg} / \mathrm{kg}$, faktor kontaminasi $656.7 \pm 65.06$ dan indek pulusi logam 0.093 pada bulan Desember 2017 sedangkan $0.64 \pm 0.217 \mathrm{mg} / \mathrm{kg}$, faktor kontaminasi $640.0 \pm 216.6$ dan indek pulusi logam 0.076 pada bulan Februari 2018. Kontaminasi Cu terhadap ikan belanak tertinggi terlihat pada bulan Desember 2017.

\section{DAFTAR PUSTAKA}

Bastami, K.D., Afkhami, M., Mohammadizadeh, M., Ehsanpour, M., Chambari, S., Aghaei, S., Esmaeilzadeh, M., Neyestani, M.R., Lagzaee, F., \& Baniamam, M., 2015., Bioaccumulation and ecological risk assessment of heavy metals in the sediments and mullet Liza klunzingeri in the northern part of the Persian Gulf. Mar. Pollut. Bull. 94:329-334. DOI : 10.1016/j.marpolbul.2015.01.019.

Bosch, A.C., O'Neill, B., Sigge, G.O., Kerwath, S.E., Hoffman, L.C., 2016. Heavy metals in marine fish meat and consumer health: a review. J. Sci. Food Agric. 96:32-48.

Çevik, F., Goksu, M.Z.L., Derici, O.B. \& Fındık, O., 2009. An assessment of metal pollution in surface sediments of Seyhan dam by using enrichment factor, geoaccumulation index and statistical analyses. Environ. Monit. Assess. 152:309317.

Eckley, C.S. \& Branfireun, B. 2009. Simulated rain events on an urban roadway to understand the dynamics of mercury mobilization in storm water runoff. Water Res. 43:3635-3646

El-Moselhy, Kh. M., Othman, A.I., El-Azem, H. Abd., \& El-Metwally. M.E.A., 2014., Bioaccumulation of heavy metals in some tissues of fish in the Red Sea, Egypt. Egyp. J. Basic App. Sci. 1: 97-195. DOI : 10.1016/j.ejbas.2014.06.001

El-Sorogy, A.S., Youssef, M., Al-Kahtany,K., \& Al-Otaiby, N., 2016. Assessment of arsenic in coastal sediments, seawaters and molluscs in the Tarut Island, Arabian Gulf, Saudi Arabia. J. African Earth Sci. 113: 6572. DOI : 10.1016/j.jafrearsci.2015.10.001

European Food Safety Authority (EFSA). 2005., Opinion of the scientific panel on contaminants in the food chain on a request from the European parliament related to the safety assessment of wild and farmed fish. EFSA J., 236:1-118

FAO, 1974. FAO Species Identification Guide for Fishery Purposes, Vol 3 : Eastern Indian Ocean - Fishing Area 57 and Western Central Pacific - Fishing Area 71. Rome, 
1974. edited by W. Fische and P.J.P. Whitehead

FAO/SIDA, 1983. Manual of methods in aqautic environment research (part 9. Analyses of metals and organochlorines in fish). FAO Fish Tech. Pap. 212, 33.

$\mathrm{FAO} / \mathrm{WHO}$. 2004. Summary of Evaluations Ferformade by the Jint FAO/WHO Expert Committee of Food Additives (JECFA 1956-2003). ILSI Press International Life Sciences Institute.pp.

Golden, C.D., Allison, E.H., Cheung, W.W. Dey, M.M., Halpern, B.S., McCauley, D.J., Smith, M., Vaitla, B., Zeller, D., Myers, S.S., 2016. Nutrition: fall in fish catch threatens human health. Nature 534:317-320

Gu, Y.G., Huang, H.H., Lin, Q., 2016. Concentrations and human health implications of heavy metals in wild aquatic organisms captured from the core area of Daya Bay's fishery resource reserve, South China Sea. Environ. Toxicol. Pharmacol. 45:90-94.

Gu, Y.G., Lin, Q., Huang, H.H., Wang, L.G., Ning, J.J., \& DU, F.Y., 2017., Heavy metals in fish tissues/stomach contents in four marine wild commercially valuable fish species from the western continental shelf of South China Sea. Mar. Pollut. Bull. 114:1125-1129

Hauser-Davis, R.A., Bordon, I.C.AC., Oliveira, T. F., \& Ziolli, R.L., 2016., Metal bioaccumulation in edible target tissues of mullet (Mugil liza) from a tropical bay in Southeastern Brazil. Journal of Trace Elements in Medicine and Biology, 36: 38-43

Jayaprakash, M., Kumar, R.S., Giridharan, L., Sujitha, S.B., Sarkar, S.K., Jonathan, M.P., 2015. Bioaccumulation of metals in fish species from water and sediments in macrotidal Ennore creek, Chennai, SE coast of India: a metropolitan city effect. Ecotoxicol. Environ. Saf. 120:243-255.

Liu, J., Cao, L,. \& Dou, S,. 2017. Bioaccumulation of heavy metals and health risk assessment in threebenthic bivalves along the coast of Laizhou Bay, China. Mar. Pollut. Bull. 117: 98-110 DOI: 10.1016/j.marpolbul.2017.01.062

Liu, J.L., Xu, X.R., Ding, Z.H., Peng, J.X., Jin, M.H., Wang, Y.S., Hong, Y.G., Yue, W.Z.,
2015. Heavy metals in wild marine fish from South China Sea: levels, tissue- and speciesspecific accumulation and potential risk to humans. Ecotoxicology 24:1583-1592

Makedonski, L., Katya Peycheva, K., \& Stancheva, M., 2017., Determination of heavy metals in selected black sea fish species. Food Control. 72:313-318. DOI : 10.1016/j.foodcont.2015.08.024

Nevárez, M., Leal, L.O., \& Moreno, M., 2015. Estimation of Seasonal Risk Caused by the Intake of Lead, Mercury and Cadmium through Freshwater Fish Consumption from Urban Water Reservoirs in Arid Areas of Northern Mexico. Int. J. Environ. Res. Public Health, 12:1803-1816; DOI 10.3390/ijerph120201803

Sapkota, A., Sapkota, A.R., Kucharski, M., Burke, J., McKenzie, S., Walker, P., Lawrence, R., 2008. Aquaculture practices and potential human health risks: current knowledge and future priorities. Environ. Int. 34:1215-1226.

Suryono, C.A., \& Rochaddi, B., 2017., Kualitas perairan di daerah fishing ground nelayan kerang di pesisir timur Kota Semarang. J. Kel. Trop. 20(1): 42-47

Suryono, C.A. \& Djunaedi, A., 2017. Logam berat $\mathrm{Pb}, \mathrm{Cr}$ dan $\mathrm{Cd}$ dalam perairan pelabuhan Tanjung Emas Semarang. J. Kel. Trop. 20(1):25 - 29

Suryono, C.A., 2016a.,Polusi logam berat antropogenik ( $\mathrm{As}, \mathrm{Hg}, \mathrm{Cr}, \mathrm{Pb}, \mathrm{Cu}$ dan $\mathrm{Fe}$ ) pada pesisir Kecamatan Tugu Kota Semarang jawa Tengah. J. Kel. Trop. 19(1):37 - 42

Suryono, C.A., 2016b., Akumulasi logam berat $\mathrm{Cr}, \mathrm{Pb}$, dan $\mathrm{Cu}$ dalam sedimen dan hubungannya dengan organisme dasar di perairan Tugu Semarang. J. Kel. Trop 19(2):143- 149

Turkmen, M., A. Turkmen., Y. Tepe., Y. Toured., A. Ates. 2009. Determination Of Metal in Fish Species from Aegean and Mediterranean Seas. Food Chemistry., 113: 233-237.

Vicente-Martorell, J.J., Galindo-Riano, M.D., García-Vargas, M., Granado-Castro, M.D. 2009. Bioavailability of heavy metals monitoring water, sediments and fish 
species from a polluted estuary. J. Hazard. Mater. 162:823-836.

Wong, C. K., Wong, P. P. K., \& Chu L. M., 2001., Heavy Metal Concentrations in Marine
Fishes Collected from Fish Culture Sites in Hong Kong., Arch. Environ. Contam. Toxicol. 40:60-69. DOI : 10.1007/s0024400 10148 